\title{
Maternal effects on the genetic evaluation of Tabapuã beef cattle
}

\author{
José Elivalto Guimarães Campêlo ${ }^{1}$, Paulo Sávio Lopes ${ }^{2}$, Robledo de Almeida Torres ${ }^{2}$, Luiz Otávio Campos \\ da Silva ${ }^{3}$, Ricardo Frederico Euclydes ${ }^{2}$, Cláudio Vieira de Araújo ${ }^{3}$ and Carmen Silva Pereira ${ }^{2}$ \\ ${ }^{1}$ Universidade Federal do Piauí, Departamento de Zootecnia, Teresina, PI, Brazil. \\ ${ }^{2}$ Universidade Federal de Viçosa, Departamento de Zootecnia, Viçosa, MG, Brazil. \\ ${ }^{3}$ Embrapa - Gado de Corte, Campo Grande, MS, Brazil.
}

\begin{abstract}
The aim of this investigation was to study the influence of maternal effects on the genetic evaluation of sire production in Tabapuã beef cattle. Single and multiple trait analyses were done with adjusted animal weights at 120, 240 and 420 days of age. Antagonism was observed between additive direct and maternal genetic effects, with the maternal effect being higher until weaning. The inclusion of maternal effects in the models removed part of the additive variance only in single trait analyses and resulted in smaller means and standard deviations for the sire breeding values. The use of maternal effect associated with single or multiple traits may affect sire ranking. The contradictory results of the single and multiple trait analyses for additive direct and maternal effects indicate that caution is needed when considering recommendations about the importance of maternal effects in Tabapuã beef cattle.
\end{abstract}

Key words: additive direct effects, beef cattle, genetic parameters, growth, maternal effects.

Received: May 16, 2003; Accepted: December 16, 2003.

\section{Introduction}

Mammalian growth during the suckling period is affected by the offspring whose growth is measured and by the dam that provides the developmental environment. The trait measured is generally the phenotypic value of the offspring and consists of at least two components, i.e., offspring growth and a maternal effect contributed by the dam. The maternal effect is strictly environmental relative to the offspring, but phenotypic differences for the maternal effect among dams are expressed in the phenotypic values of the offspring (Willham, 1972). According to Robison (1981), the importance of maternal influence on the growth of young mammals has been recognized since the earliest attempts to improve livestock production. Cundiff (1972) indicated that maternal effects are more important than direct gene effects during the early postnatal growth of young suckling their mothers. Later in life, the maternal influence diminishes and direct effects of the genes that influence growth assume primary importance.

The presence of maternal effects in the models used to genetic evaluation reduces the variance of direct genetic effects (Meyer, 1992). Part of this reduction is explained by

Send correspondence to José Elivalto Guimarães Campêlo. Universidade Federal do Piauí, Departamento de Zootecnia, 64049-550 Teresina, PI, Brazil. E-mail: elivalto@ ufpi.br. maternal genetic and maternal permanent environmental variances. Since antagonism has been observed between direct and maternal effects, a knowledge of the maternal influence on pre- and post-weaning weights, and of the correlation between these effects, is fundamental for achieving unbiased heritability estimates. Another aspect that needs to be considered in beef cattle is the fact that the largest portion of the response to selection is directly influenced by the choice of sires because of their intensive use in the herd. Selection of the best sires is desirable in order to increase male performance for productive traits and to improve the maternal performance of females.

The aim of this study was to evaluate the importance of including maternal effects in single and multiple trait analyses of the variance component estimates of preweaning, weaning and post-weaning weights of Tabapuã beef cattle.

\section{Material and Methods}

The data were obtained from the body weight control program of the Tabapuã Beef Cattle Herd registered in the National Records of the breed belonging to the Brazilian Zebu Breeders Association (ABCZ) and were provided by Embrapa-Beef Cattle, in agreement with the Ministry of Agriculture. The pre-weaning, weaning and post-weaning weights adjusted at 120, 240 and 420 days of age, respec- 
tively, for animals born from 1975 to 1998 and raised under pasture conditions were used.

The models used in single or multiple trait analyses considered the fixed effects of contemporary groups (animals of the same sex, herd, year and season of birth), the age of the cow as a covariate (linear and quadratic effects), and the random effects of animal, dam and error. The months of birth of the animals were divided into groups 1 and 2 corresponding to the dry season (April to September) and the rainy season (October to March), respectively.

The numerator relationship matrix (NRM) was obtained from the pedigree files of 46,296 animals. Of these, 312 were inbred, with an average inbreeding coefficient of $0.11 \%$. The number of records and the means and standard deviations of the weights at 120,240 and 420 days of age are shown in Table 1.

The inclusion of the maternal effects in the models was tested in single or multiple trait analyses by the likelihood ratio test. The statistics of the likelihood ratio (LRij) test for sequentially reduced models (Rao, 1973) are:

$$
L R i j=-2 \log _{e}\left(L_{j} / L_{i}\right)=2 \log _{e} L_{i}-2 \log _{e} L_{j},
$$

where $\mathrm{L}_{\mathrm{i}}$ is the maximum likelihood for the complete model (with the maternal effect) and $\mathrm{Lj}$ is the maximum likelihood for the reduced model (without the maternal effect).

In matrix notation, the statistical model is:

$$
\mathrm{Y}=\mathrm{Xb}+\mathrm{Za}+\mathrm{Wm}+\mathrm{e},
$$

where $\mathrm{y}$ is the vector $\mathrm{n} x$ of the adjusted weight at standard ages, $\mathrm{X}$ is the matrix $\mathrm{n} \mathrm{x}$ fof incidence for fixed effects and covariate, $\beta$ is the vector $\mathrm{f} x 1$ of fixed effects and covariate, a is the vector $\mathrm{n} \times 1$ of additive direct genetic values, $\mathrm{m}$ is the vector $\mathrm{n} x 1$ of additive maternal genetic values, and $\mathrm{W}$ are the matrix $\mathrm{n} \mathrm{x} \mathrm{n}$ of incidence for direct and maternal genetic values, respectively, and $\underline{\mathrm{e}}$ is the vector of residual effects.

The assumptions concerning the distribution of $\mathrm{y}, \mathrm{a}$, $\mathrm{m}$ and $\mathrm{e}$ are:

$$
\left[\begin{array}{c}
\mathrm{y} \\
\mathrm{a} \\
\mathrm{m} \\
\mathrm{e}
\end{array}\right] \sim\left[\begin{array}{c}
\mathrm{X} \beta \\
0 \\
0 \\
0
\end{array}\right]\left[\begin{array}{cccc}
\mathrm{ZGZ}{ }^{\prime}+\mathrm{WMW}^{\prime}+\mathrm{R} & \mathrm{ZG} & \mathrm{WM} & \mathrm{R} \\
\mathrm{GZ} & \mathrm{G} & \phi & \phi \\
\mathrm{MW}, & \phi & \mathrm{M} & \phi \\
\mathrm{R} & \phi & \phi & \mathrm{R}
\end{array}\right]
$$

where $G=A \sigma_{a}^{2}, M=A \sigma_{m}^{2}$ and $R=I \sigma_{e}^{2}$ for single trait analyses, $\mathrm{G}=\mathrm{A} \otimes \mathrm{G}_{0}, \mathrm{M}=\mathrm{A} \otimes \mathrm{M}_{0}$ and $\mathrm{R}=\mathrm{I} \otimes \mathrm{R}_{0}$ for multiple trait analyses, $\mathrm{A}$ is the numerator relationship matrix, of an order equal to the number of individuals, and $\mathrm{G}_{0}, \mathrm{M}_{0}$ and $\mathrm{R}_{0}$ are the matrices q $\mathrm{x}$ q, of direct, maternal and residual genetic variances, respectively, among $\mathrm{q}$ traits.

Estimates of covariance components and predicted breeding values were obtained using the MTDFREML (Multiple Trait Derivative - Free Restricted Maximum Likelihood) program (Boldman et al., 1995). As a convergence criterion, the variance of the values of the function $-2 \log \lambda$ of simplex, was considered to be smaller than $10^{-9}$.

Total genetic effect heritability $\left(\mathrm{h}_{\mathrm{T}}^{2}\right)$ of adjusted weights was estimated as (Willham, 1972):

$$
\mathrm{h}_{\mathrm{T}}^{2}=\frac{\sigma_{\mathrm{a}}^{2}+0.5 \sigma_{\mathrm{m}}^{2}+1.5 \sigma_{\mathrm{am}}}{\sigma_{\mathrm{P}}^{2}}
$$

where $\sigma_{\mathrm{P}}^{2}$ is the phenotypic variance of the trait, as follows:

$$
\sigma_{\mathrm{P}}^{2}=\sigma_{\mathrm{a}}^{2}+\sigma_{\mathrm{m}}^{2}+\sigma_{\mathrm{am}}+\sigma_{\mathrm{e}}^{2}
$$

\section{Results}

The values of minus twice the natural logarithm of the likelihood function $\left(-2 \log _{\mathrm{e}} \mathrm{L}\right)$ and the likelihood ratio test used to evaluate the significance of the maternal effect in the model for adjusted weights analyzed as single and multiple traits are shown in Table 2. The inclusion of the maternal effects in the models was significant $(p<0.01)$ for all adjusted weights in all analyses.

The variance components and genetic parameter estimates obtained by single trait analyses with and without maternal effect are shown in Table 3. Although the likelihood ratio test did not provide statistical evidence of a lack of maternal effects on post-weaning weight (420 days of age), the smallest variance components and the maternal

Table 1 - Number of records, contemporary groups, sires, means and phenotypic standard deviations for the adjusted weights at 120,240 and 420 days of age.

\begin{tabular}{lccc}
\hline Item & \multicolumn{3}{c}{ Adjusted weight at } \\
\cline { 2 - 4 } & 120 days of age & 240 days of age & 420 days of age \\
\hline Number of records & 35,478 & 34,303 & 26,892 \\
Contemporary group & 763 & 751 & 704 \\
Number of sires & 478 & 478 & 476 \\
Number of dams & 19,077 & 18,370 & 13,831 \\
Mean (kg) & 117.96 & 193.69 & 245.36 \\
Phenotypic standard deviation & 19.59 & 31.28 & 37.84 \\
\hline
\end{tabular}


genetic parameter estimates indicated a reduced importance of this effect for weights at older ages.

Table 2 - Values of minus twice the natural logarithm of the likelihood function $\left(-2 \log _{\mathrm{e}} \mathrm{L}\right)$ and the likelihood ratio (LRij) test for the adjusted weights at 120,240 and 420 days of age.

\begin{tabular}{lccc}
\hline & \multicolumn{2}{c}{$-2 \log _{\mathrm{e}} \mathrm{L}$} & LRij \\
\cline { 2 - 3 } & $\begin{array}{c}\text { With maternal } \\
\text { effect }\end{array}$ & $\begin{array}{c}\text { Without } \\
\text { maternal effect }\end{array}$ & \\
\cline { 2 - 3 } $\begin{array}{l}\text { Adjusted } \\
\text { weight at }\end{array}$ & \multicolumn{2}{c}{ Single trait analyses } \\
\hline 120 days of age & $229,742.67$ & $229,967.65$ & $224.9^{* *}$ \\
240 days of age & $255,041.23$ & $255,375.60$ & $334.4^{* *}$ \\
420 days of age & $207,966.04$ & $207,997.53$ & $31.5^{* *}$ \\
\hline & \multicolumn{2}{c}{ Multiple trait analyses ${ }^{1}$} & \\
\cline { 2 - 3 } 120 days of age & $456,913.89$ & $457,080.19$ & $166.89^{* *}$ \\
240 days of age & $412,399.68$ & $412,531.23$ & $131.55^{* *}$ \\
420 days of age & $430,152.06$ & $430,263.49$ & $111.43^{* *}$ \\
\hline
\end{tabular}

${ }^{1}$ Multiple trait analyses using the combinations of the adjusted weight at 120 days of age with the adjusted weights at 240 and 420 days of age. $* * p<0.01$
In single trait analyses including the maternal effect, the heritability estimates of direct effects were small $(0.17$, 0.15 , and 0.12 for adjusted weights at 120,240 and 420 days, respectively). Without maternal effect, these values were $0.28,0.29$ and 0.15 , respectively. However, the total heritability estimates were $0.14,0.12$ and 0.12 for adjusted weights at 120, 240 and 420 days of age, respectively.

The variance components and genetic parameter estimates obtained by multiple trait analyses for adjusted weights at different ages, with and without the maternal effect, are shown in Table 4. For the adjusted weight at 420 days of age, with maternal effect, a difficulty was observed in approaching the convergence at the predetermined simplex variance level, probably because of the reduced size of the data set.

Multiple trait analyses with adjusted weights at different ages showed that the heritabilities of direct genetic effects were not strongly affected by the maternal effects, with values of 0.20 and 0.22 being obtained for adjusted weight at 420 days of age with and without maternal effect, respectively. These values were considered to be relatively low. The maternal heritability estimates were also low

Table 3 - Estimates of additive direct $\left(\sigma_{\mathrm{a}}^{2}\right)$, maternal $\left(\sigma_{\mathrm{m}}^{2}\right)$ and residual $\left(\sigma_{\mathrm{e}}^{2}\right)$ variances, direct maternal genetic correlations $\left(\mathrm{r}_{\mathrm{am}}\right)$, and direct $\left(\mathrm{h}_{\mathrm{a}}^{2}\right)$, maternal $\left(\mathrm{h}_{\mathrm{m}}^{2}\right)$ and total $\left(\mathrm{h}_{\mathrm{T}}^{2}\right)$ heritabilities obtained by single trait analyses.

\begin{tabular}{|c|c|c|c|c|c|c|}
\hline \multirow{3}{*}{ Parameter } & \multicolumn{3}{|c|}{ Model with maternal effects } & \multicolumn{3}{|c|}{ Model without maternal effects } \\
\hline & \multicolumn{3}{|c|}{ Adjusted weight at } & \multicolumn{3}{|c|}{ Adjusted weight at } \\
\hline & 120 days of age & 240 days of age & 420 days of age & 120 days of age & 240 days of age & 420 days of age \\
\hline$\sigma_{\mathrm{a}}^{2}$ & 44.69 & 107.35 & 119.31 & 77.75 & 214.01 & 148.50 \\
\hline$\sigma_{\mathrm{m}}^{2}$ & 36.38 & 121.05 & 44.90 & & & \\
\hline$\sigma_{\mathrm{e}}^{2}$ & 204.67 & 547.00 & 826.04 & 198.74 & 528.70 & 830.97 \\
\hline $\mathrm{r}_{\mathrm{am}}$ & -0.40 & -0.48 & -0.21 & & & \\
\hline $\mathrm{h}_{\mathrm{a}}^{2}$ & 0.17 & 0.15 & 0.12 & & & \\
\hline $\mathrm{h}_{\mathrm{m}}^{2}$ & 0.13 & 0.17 & 0.05 & 0.28 & 0.29 & 0.15 \\
\hline $\mathrm{h}_{\mathrm{T}}^{2}$ & 0.14 & 0.12 & 0.12 & & & \\
\hline
\end{tabular}

Table 4 - Estimates of additive direct $\left(\sigma_{\mathrm{a}}^{2}\right)$, maternal $\left(\sigma_{\mathrm{m}}^{2}\right)$ and residual $\left(\sigma_{\mathrm{e}}^{2}\right)$ variances, direct maternal genetic correlations $\left(\mathrm{r}_{\mathrm{am}}\right)$ and direct $\left(\mathrm{h}_{\mathrm{a}}^{2}\right)$, maternal $\left(\mathrm{h}_{\mathrm{m}}^{2}\right)$ and total $\left(\mathrm{h}_{\mathrm{T}}^{2}\right)$ heritabilities obtained by multiple trait analyses ${ }^{1}$.

\begin{tabular}{|c|c|c|c|c|c|c|}
\hline \multirow{3}{*}{ Parameter } & \multicolumn{3}{|c|}{ Model with maternal effect } & \multicolumn{3}{|c|}{ Model without maternal effect } \\
\hline & \multicolumn{3}{|c|}{ Adjusted weight at } & \multicolumn{3}{|c|}{ Adjusted weight at } \\
\hline & 120 days of age & 240 days of age & 420 days of age ${ }^{2}$ & 120 days of age & 240 days of age & 420 days of age \\
\hline$\sigma_{\mathrm{a}}^{2}$ & 92.53 & 219.36 & 222.64 & 84.20 & 229.73 & 196.49 \\
\hline$\sigma_{\mathrm{m}}^{2}$ & 15.59 & 57.26 & 12.63 & & & 810.72 \\
\hline$\sigma_{\mathrm{e}}^{2}$ & 186.23 & 509.91 & 808.53 & 194.37 & 521.91 & \\
\hline $\mathrm{r}_{\mathrm{am}}$ & -0.40 & -0.40 & -0.37 & & & \\
\hline $\mathrm{h}_{\mathrm{a}}^{2}$ & 0.33 & 0.29 & 0.22 & 0.30 & 0.31 & 0.20 \\
\hline $\mathrm{h}_{\mathrm{m}}^{2}$ & 0.06 & 0.08 & 0.01 & & & \\
\hline $\mathrm{h}_{\mathrm{T}}^{2}$ & 0.28 & 0.25 & 0.21 & & & \\
\hline
\end{tabular}

${ }^{1}$ Multiple trait analyses using the combinations of adjusted weight at 120 days of age with the adjusted weights at 240 and 420 days of age. 
(0.06, 0.08 and 0.01 for the adjusted weights at 120, 240 and 420 days of age, respectively).

Sire breeding values (mean $\pm \mathrm{SD}$ ) for adjusted weights at 120,240 and 420 days of age obtained by single trait analyses, with or without maternal effects, and multiple trait analyses with adjusted weights at different ages, with maternal effects, are shown in Table 5. When single trait analyses were used, the model without maternal effect gave higher mean sire breeding values because of the higher estimates for the additive direct variances observed with this model.

\section{Discussion}

Pre-weaning and weaning weights were similar to those observed for the Nellore breed by Mercadante and Lôbo (1997), Ferreira (1999), Ferraz-Filho et al. (2000) and Mercadante et al. (2000), who reported the importance of maternal effects on beef cattle, mainly during the pre-weaning phase.

When the parameters obtained in the models with and without maternal effects were compared (Table 3 ), the single trait model (without maternal effect) appeared to overestimate the additive direct variance and, consequently, the potential response to selection, ignoring the negative covariance between the direct and maternal additive genetic effects. Similar results were reported by Mercadante and Lôbo (1997), Ferreira (1999), Scarpati and Lôbo (1999) and Sousa et al. (1999). The maternal contribution to the variance of adjusted weights in the single trait analyses was similar to the direct contribution at 120 and 240 days of age, but was much lower for the adjusted weight at 420 days of age, as also reported by Sousa et al. (1999).

The lowest additive genetic values observed in the analyses with maternal effects agreed with those reported by Notter et al. (1992), who stated that the estimates of additive direct parameters decrease when maternal effects are included in the model. The lower heritability observed for the adjusted weight at 420 days of age could be attributed to the selection applied to previous weights. Values of small magnitude for these parameters were reported by Ferreira (1999) for the Nellore breed, for a much smaller data set. According to Willham (1972), for traits subject to maternal influence, total heritability $\left(\mathrm{h}_{\mathrm{T}}^{2}\right)$ could become the main determinant of response to selection.

The direct heritability values obtained by multiple trait analyses (Table 4) for the adjusted weights at 120 and 240 days of age were close to those observed in single trait analyses without maternal effects (Table 3). In this case, there was no overestimation of additive direct variance, as indicated by the results of the single trait analyses.

Multiple trait analyses showed that the Tabapuã breed has additive genetic variability for growth traits, indicating that the breed has a genetic potential for the response to selection. However, in an analysis of data obtained for the Tabapuã breed, Ferraz Filho et al. (2000) found direct heritabilities of $0.16,0.17$ and 0.13 for adjusted weights at 205,365 and 550 days of age, indicating that the genetic progress in these traits by selection may not be high.

Besides the possible selection effects, the lowest direct heritabilities for adjusted weight at 420 days of age observed in multiple trait analyses may also be a consequence of post-weaning compensatory growth, which most of the time is a result of environmental stress affecting the dams before weaning and results in lower milk production. Thus, the calf is forced to start feeding on pasture earlier, which reduces the stress during weaning and compensates for the reduced growth during the pre-weaning period.

The maternal heritability estimates obtained by multiple trait analyses were lower than those obtained by single trait analyses, indicating inconsistent results for maternal effects obtained by the two types of analyses. The low relevance of maternal components in multiple trait analyses was confirmed despite the expressive correlations between the direct and maternal additive effects, thus suggesting that field data limit the quality of maternal effect estimates, as pointed out by Sousa et al. (1999). This finding is probably reflects the small number of calves per cow and the fact that cows had all their productions in a single herd. However, the lack of consistency between the results of the sin-

Table 5 - Means and standard deviations of the breeding values of sires for the adjusted weights at 120,240 and 420 days of age obtained by single trait analyses in the model with and without maternal effects, and multiple trait analyses for adjusted weights at different ages with maternal effects in the model.

\begin{tabular}{|c|c|c|c|c|c|c|}
\hline \multirow[t]{3}{*}{ Analysis } & \multicolumn{6}{|c|}{ Breeding value for adjusted weight at } \\
\hline & \multicolumn{2}{|c|}{120 days of age } & \multicolumn{2}{|c|}{240 days of age } & \multicolumn{2}{|c|}{420 days of age } \\
\hline & Mean & Standard deviation & Mean & Standard deviation & Mean & Standard deviation \\
\hline \multicolumn{7}{|l|}{ Single trait } \\
\hline Without maternal effect & 1.353 & 5.974 & 2.264 & 9.567 & 2.163 & 8.750 \\
\hline With maternal effect & 0.639 & 4.914 & 1.099 & 7.604 & 1.684 & 7.899 \\
\hline \multicolumn{7}{|l|}{ Multiple trait } \\
\hline With maternal effect ${ }^{1}$ & 1.727 & 6.223 & 2.787 & 9.835 & 3.180 & 10.062 \\
\hline
\end{tabular}

\footnotetext{
${ }^{1}$ Multiple trait analyses using the combinations of the adjusted weight at 120 days of age with the adjusted weights at 240 and 420 days of age.
} 
gle and multiple trait analyses raises doubts about the perspective of obtaining genetic progress in the mothering ability of Tabapuã cows by selection.

The antagonism between direct and maternal additive effects was well characterized by the correlations between these effects for the single trait $(r=-0.40$ and -0.48 , respectively, for pre-weaning and weaning weights) (Table 3 ) and multiple trait analyses for the adjusted weights at 120 and 240 days of age $(r=-0.40$ for both weights) (Table 4). According to Robison (1981), the negative correlation between the direct and maternal additive effects and the high magnitude of the values may reduce the efficiency of progeny tests.

Specifically for body weight at 240 days of age using single trait analyses (Table 3 ), the negative correlation indicated a higher maternal effect than direct heritability. This result indicates that single trait analysis was able to detect the response of the animals to weaning management, which generally occurs at this age. A similar finding was also reported by Sakaguti (2000), who analyzed data for the Tabapuã breed using random regression models.

When single trait analyses were used, the model without maternal effect gave higher sire breeding values (mean $\pm \mathrm{SD}$ ) because of the higher estimates of additive direct variances. Again, the presence of maternal effects tended to remove part of the additive direct variance, as indicated by Notter et al. (1992) and Meyer (1992). The higher sire breeding values (mean $\pm \mathrm{SD}$ ) obtained with multiple trait analyses when compared to those obtained by single trait analyses agreed with data reported by Freitas (2000), who observed that the estimation method and the use of single or multiple trait analyses were the main causes of changes in the heritability estimates.

\section{Conclusions}

Direct heritability and the response to selection are overestimated in single trait analyses when maternal effects are not considered. The higher heritability estimates obtained using multiple trait analyses demonstrated that the additive genetic component was recovered in this type of analysis because of the increase in the amount of information and inclusion of the genetic correlation between traits.

\section{Acknowledgments}

We would like to thank the Embrapa Beef Cattle Brazilian Agricultural Research Corporation for providing the data for this study.

\section{References}

Boldman KG, Kriese LA, Van Vleck LD, Van Tassel CP and Kachman SD (1995) A Manual for Use of MTDFREML. A Set of Programs to Obtain Estimates of Variances and Covariances (DRAFT). U.S. Department of Agriculture, Agriculture Research Service, Lincoln, NE, 120 pp.

Cundiff L (1972) The role of maternal effects in animal breeding: VII - Comparative aspects of maternal effects. J Anim Sci 35:1335-1337.

Ferraz-Filho PB, Ramos AA, Silva LOC, Souza JC, Alencar MM and Diniz FCP (2000) Herdabilidades e correlações genéticas para características de crescimento de animais da raça Tabapuã. Anas da Reunião Anual da Sociedade Brasileira de Zootecnia, Viçosa, Minas Gerais, Brazil, p 232.

Ferreira VCP (1999) Interação genótipo - Ambiente de algumas características produtivas em gado de corte no Brasil. MSc dissertation, Universidade Federal de Minas Gerais, Belo Horizonte.

Freitas AR de (2000) Avaliação de procedimentos na estimação de parâmetros genéticos em bovinos de corte. Rev Bras Zootec 29:94-102.

Mercadante MEZ and Lôbo RB (1997) Estimativas de (co)variâncias e parâmetros genéticos dos efeitos direto e materno de características de crescimento de fêmeas de um rebanho nelore. Rev Bras Zootec 26:1124-1133.

Mercadante MEZ, Lôbo RB and Oliveira HN (2000) Estimativas de (co)variâncias entre características de reprodução e de crescimento em fêmeas de um rebanho nelore. Rev Bras Zootec 29:997-1004.

Meyer K (1992) Variance components due to direct and maternal effects for growth traits of Australian beef cattle. Livest Prod Sci 31:179-192.

Notter DR, Tier B and Thrift FA (1992) Sire x herd interaction for weaning weight in beef cattle. J Anim Sci 70:2359-2365.

Rao CR (1973) Linear Statistical Inference and its Applications. 2nd edition. John Wiley \& Sons, New York, 522 pp.

Robison OW (1981) The influence of maternal effects on the efficiency of selection: A review. Livest Prod Sci 8:121-137.

Sakaguti ES (2000) Funções de covariâncias e modelos de regressão aleatória na avaliação genética do crescimento de bovinos jovens da raça tabapuã. $\mathrm{PhD}$ Thesis, Universidade Federal de Viçosa, Viçosa.

Scarpati MTV and Lôbo RB (1999) Modelos animais alternativos para estimação de componentes de (co)variâncias e de parâmetros genéticos e fenotípicos do peso aos nascer na raça nelore. Rev Bras Zootec 28:512-518.

Sousa WH, Pereira CS, Bergmann JAG and Silva FLR (1999) Estimativas de componentes de (co)variância e herdabilidade direta e materna de pesos corporais em ovinos da raça Santa Inês. Rev Bras Zootec 28:1252-1262.

Willham RL (1972) The role of maternal effects in animal breeding: III - Biometrical aspects of maternal effects in animals. J Anim Sci 35:1288-1293.

Associate Editor: Pedro Franklin Barbosa 